\title{
Energy harvesting from human motions for wearable applications
}

CAO WENYING

YU WEIDONG
DOI: $10.35530 / I T .069 .05 .1531$

LI ZHAOLING

\section{REZUMAT - ABSTRACT}

\section{Captarea energiei din mișcările umane pentru aplicații portabile}

Captarea energiei biomecanice din mișcarea umană este o soluție alternativă pentru a alimenta eficient sistemele electronice portabile. În acest studiu au fost dezvoltate două dispozitive de captare a energiei piezoelectrice, pe bază de impact, care pot fi integrate în tălpile de încălțăminte și pot fi, de asemenea, adaptate pentru a fi integrate în covoarele comercializate sau în carosabilul exterior pentru a capta energia mecanică masivă de la vehiculele care se deplasează sau de la un grup de oameni la frecvențe reduse. Pentru un studiu cuprinzător, au fost selectate și testate două tipuri de dispozitive de captare PVDF. S-a demonstrat că răspunsurile mecanice ale prototipului tip arc și ale prototipului de tip C sunt diferite. În plus, răspunsul mecanic al tipului C poate fi afectat de înălțimea verticală a tipului C. Tensiunea de vârf a tipului C crește odată cu scăderea înălțimii verticale a tipului $C$. Tensiunea de vârf a tipului arc este aproape aceeași cu cea a tipului C, când înălțimea verticală este de $25 \mathrm{~mm}$. Stabilitatea tensiunii de ieșire a tipului arc este cea mai scăzută în comparație cu cea a celor trei tipuri C. Stabilitatea tensiunii de ieșire a tipului C în cazul în care înălțimea verticală este de $25 \mathrm{~mm}$ este cea mai scăzută dintre cele trei înălțimi verticale diferite.

Cuvinte-cheie: piezoelectric, dispozitiv de captare a energiei, mișcări umane, frecvență scăzută, portabil

\section{Energy harvesting from human motions for wearable applications}

Harvesting biomechanical energy from human's movement is an alternative solution to effectively power the wearable electronics. In this paper, two impact-driven piezoelectric energy harvesters were developed which can be integrated within human shoe-soles and also can be tailored to integrate in commercial carpets or outdoor roadway to harvest the massive mechanical energy from the passing vehicles or people crowds at low frequencies. For a comprehensive study, two buckling types of PVDF harvesters were selected and tested. It has been shown that the mechanical responses of the arch type prototype and the $C$ type prototype are different. In addition, the mechanical response of the $C$ type can be affected by the vertical height of the $C$ type. The peak-peak voltage of the $C$ type increases with the vertical height of the $C$ type decreases. The peak-peak voltage of arch type is almost the same with the $C$ type when the vertical height of which is $25 \mathrm{~mm}$. The stability of the output voltage of the arch type is the worst when compared with that of the three $C$ types. The stability of the output voltage of the C type when the vertical height of which is $25 \mathrm{~mm}$ is the worst among the three different vertical heights.

Keywords: piezoelectric, energy harvester, human motions, low frequency, wearable

\section{INTRODUCTION}

Energy harvesting from human body's movement has become a widespread issue due to its versatile capability serving as a clean and renewable energy system to power some low-power consumption electronic devices [1-3]. Several working mechanisms or concepts can be used to fabricate a human energy harvester, such as electromagnetic [4], electrostatic [5], thermoelectric [6], triboelectric [7], piezoelectric [1] and biofuel cell [8]. Among them, the piezoelectric energy harvester has attracted much more research attention because of its simple structure and great potential to convert the mechanical energy into electricity in an direct and high-efficiency manner [9-10]. The piezoelectric energy conversion occurs because the piezoelectric molecular structure is oriented such that the material exhibits a local charge separation, known as an electric dipole. When a stress is applied to the material it cause a strain, so it results in a deformation of the electric dipole and the formation of a charge that can be removed from the material and used to power various electric devices [11]. Perhaps the most common and effective type of piezoelectric human energy harvester is integrating the piezoelectric materials into shoes due to the large amount of power generation from walking or running in daily life [12-14].

To adapt to the low-frequency walking condition and overcome the limitations of the shoes' structure, most current studies of shoe-equipped piezoelectric transducers focus on the following three types, namely flat plate type, arch type and cantilever type [10]. Kymissis explored an insole made of eight-layer stacks of PVDF sheets with a flexible plastic substrate to harness the energy dissipated in bending of the sole and the average power reached $1.1 \mathrm{~mW}$ at $1 \mathrm{~Hz}$ [14]. Zhao developed a shoe-embedded piezoelectric energy harvester, which was readily compatible with a shoe [1]. The harvester was based on a sandwich structure and there was a multilayered PVDF film sandwiched between the two wavy surfaces. Moro presented a rectangular piezoelectric cantilever based on PZT, which was mounted inside the shoe heel using a conventional clamp system 
without loss of comfort or radical change in shoe design [15]. Ansari designed horizontal and vertical buckling harvesters placed on the road to scavenge the mechanical energy from passing vehicle or walking people [16]. To the best knowledge of the authors, there is no literature mentioned on the study of vertical buckling harvester mounted on the shoe to harvest human's biomechanical energy, especially the comparison study of horizontal and vertical buckling harvesters.

In this research, two kinds of piezoelectric buckling harvesters, which were horizontally and vertically configured were investigated and compared. A series of experiments were carried out to characterize the harvester prototypes, which finally proved that the fabricated harvesters can be served as a sustainable and wearable power supply for low power consumption electronic devices.

\section{HARVESTER DESIGN AND FABRICATION}

Lead zirconate titanate (PZT) and polyvinylidene difluoride (PVDF) are the most common piezoelectric materials for energy harvesting owing to their high piezoelectric performance. Considering the PVDF has a considerably better flexibility compared with the $\mathrm{PZT}$, the harvester proposed in this paper is based on the PVDF. The selected PVDF units are integrated with aluminum layer electrodes.

Two prototypes of the 31-mode harvesters are fabricated for two different purposes. Prototype 1 is horizontally configured, which designed as an arch type, the schematic diagram and the finished prototype are shown in figure 1, a. In this regard, the PVDF will contact directly the heel. Prototype 2 is vertically configured, which designed as a C type, the schematic diagram and the finished prototype are shown in figure $1, b$. The PVDF will not contact the heel in a direct way and thus this reduces the damage of the PVDF compared with the prototype 1 . The prototype 1 is a common type in previous studies, the purpose of this design in here is to compare with prototype 2.
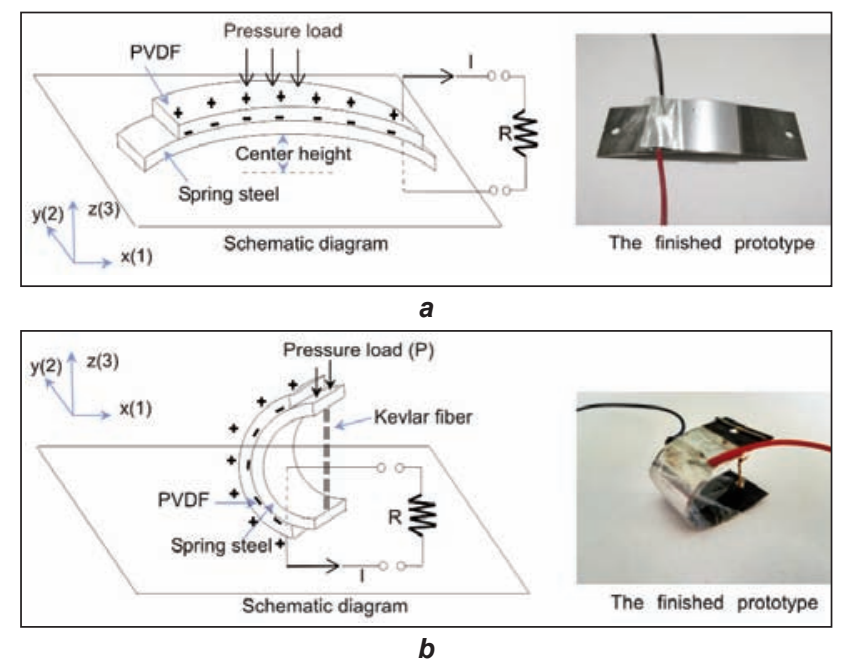

Fig. 1. Schematic diagram of different structural piezoelectric energy harvesters: a - Prototype 1: arch type; b- Prototype 2: C type
The two kinds of harvesters all can be mounted to the insole of the heel. The PVDF layer could generate electricity when it is deformed and returns back to the non-deformed shape periodically. When the external force is removed, the working unit returns to its original position.

The two harvesters consist of two major components: the top PVDF layer and the bottom spring steel substrate. These two layers are bonded together by a thin adhesive layer. The PVDF layer is in the middle of the curved spring steel layer, whose length, width, and thickness dimensions are 70,20 , and $0.33 \mathrm{~mm}$, respectively. The center height of arch type harvester is set as $5 \mathrm{~mm}$. When the descent height of the two prototypes is fixed to $5 \mathrm{~mm}$, the height of $C$ type harvester is more adjustable. Considering the shape of the shoe's heel, three specifications of the vertical height of $\mathrm{C}$ type harvester are chosen, which are $30 \mathrm{~mm}, 25 \mathrm{~mm}, 20 \mathrm{~mm}$. The corresponding C type harvesters are named prototype $2 \mathrm{a}$, prototype $2 \mathrm{~b}$ and prototype 2c, respectively. The kevlar fiber is chosen to adjust the height of the prototype 2 due to it's high strength and high modulus, which resulted in the vertical height of $C$ type harvesters can be controlled well. The other geometric and material parameters of PVDF are listed in table 1.

\begin{tabular}{|c|c|}
\hline & Table 1 \\
\hline Parameters & Value \\
\hline $\mathrm{d}_{33}(\mathrm{PC} / \mathrm{N})$ & 21 \\
\hline $\mathrm{d}_{31}(\mathrm{PC} / \mathrm{N})$ & 17 \\
\hline Coupling coefficient $\mathrm{k}_{33}(\%)$ & $10 \sim 14$ \\
\hline Density $\left(\mathrm{kg} / \mathrm{m}^{3}\right)$ & $1.78 \times 10^{3}$ \\
\hline Relative permittivity & $9.5 \pm 1.0$ \\
\hline Elastic modulus $(\mathrm{MPa})$ & 2500 \\
\hline Length $\times$ width $\times$ thickness $(\mathrm{mm} \times \mathrm{mm} \times \mathrm{mm})$ & $30 \times 20 \times 0.03$ \\
\hline
\end{tabular}

\section{EXPERIMENTS}

To compare these two kinds of harvesters, the power harvesters tested was based on a simple force excitation generator which can provide an impulse force and can constrain the axial deformation easily, the illustration of the force excitation generator is shown in figure 2. The output voltages of two prototypes were measured by the oscilloscope. During testing, the harvester was fixed to the buffer board and the impulse force was set to $500 \mathrm{~N}$. The axial deformation of prototype 1 and prototype 2 were constrained to $5 \mathrm{~mm}$ by adjusting the location of buffer board. For the purpose of preventing the damage of the PVDF under excessive deformations, we limited the amount of axial deformation.

To test the output voltages of the harvesters, the force frequency of the force excitation generator was set as $1 \mathrm{~Hz}$. During testing, the output of the harvesters was terminated into the oscilloscope to measure the output voltage. The internal resistance of the oscilloscope is $10 \mathrm{M} \Omega$, serving as a resistive load. 

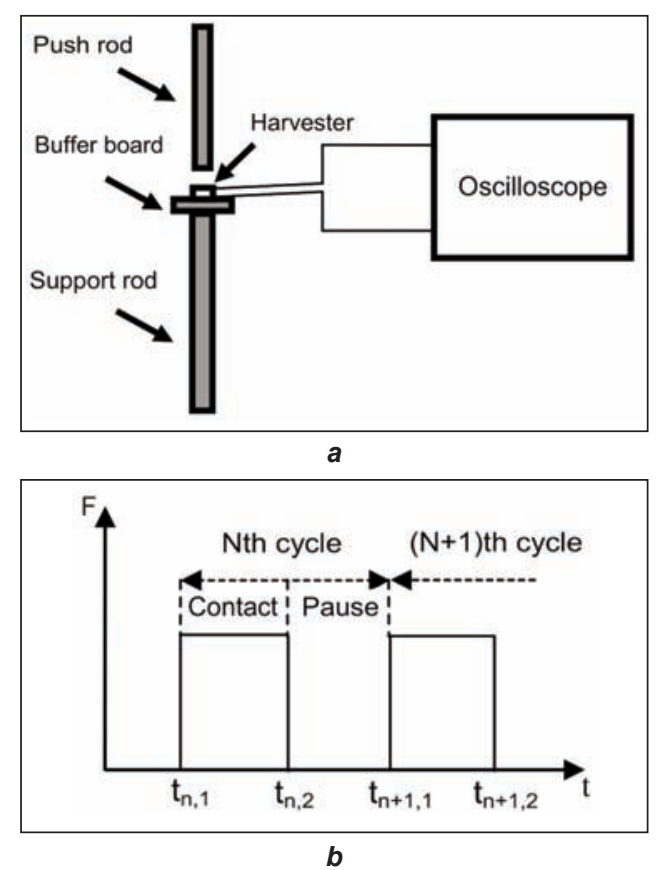

Fig. 2. The illustration of the simple force excitation generator: $a$ - structure; $b$ - schematic

\section{RESULTS AND DISCUSSION}

The single voltage waveforms created by the harvesters at a $1 \mathrm{~Hz}$ impulse force can be seen in figure 3 , which shows the impulse response of the harvesters. It can be seens different from that of prototype 2, which means that the mechanical responses of the two types are different. The similarity of the plots between the prototype $2 \mathrm{a}$ and prototype $2 \mathrm{~b}$ indicates that there are no significant differences between the mechanical responses of the prototype $2 a$ and prototype $2 b$. But the plot of prototype $2 \mathrm{c}$ is different from that of the prototype $2 a$ and prototype $2 b$, which means that when the vertical height reaches a certain value, it can influence the mechanical responses of the prototype 2 .
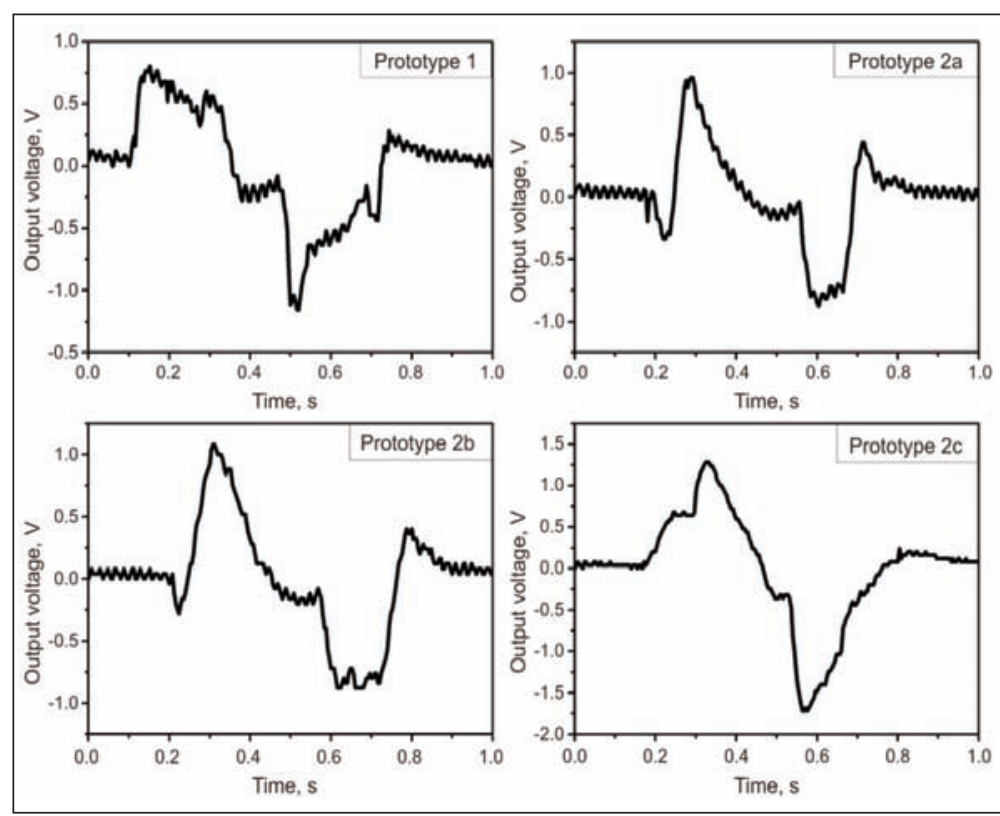

Fig. 3. The single actuation of the two harvester

Figure 4, a compares the results of the peak-peak voltages of the two prototypes. It can tell that the corresponding peak power which calculated by the equation $P=U^{2} / R$ of the harvesters is at the $\mu \mathrm{W}$ level. In addition, the figure 4 , a shows that the prototype 1 can produce approximately the same voltage of the prototype $2 b$, the differences are not so significant. For the prototype 2, the peak-peak voltage of the prototype $2 \mathrm{c}$ is the biggest, that of the prototype $2 a$ is the smallest. From the test results it can be seen that the peak-peak voltage increases with the vertical height of prototype 2 decreases. The coefficient of variation (CV) of output voltage reflects the stability of the output voltage of the harvester. Figure $4, b$ shows the CV of the peak-peak output voltages of the prototypes, it can be seen that the $\mathrm{CV}$ of the prototype 1 is the biggest and the prototype $2 a$ is the
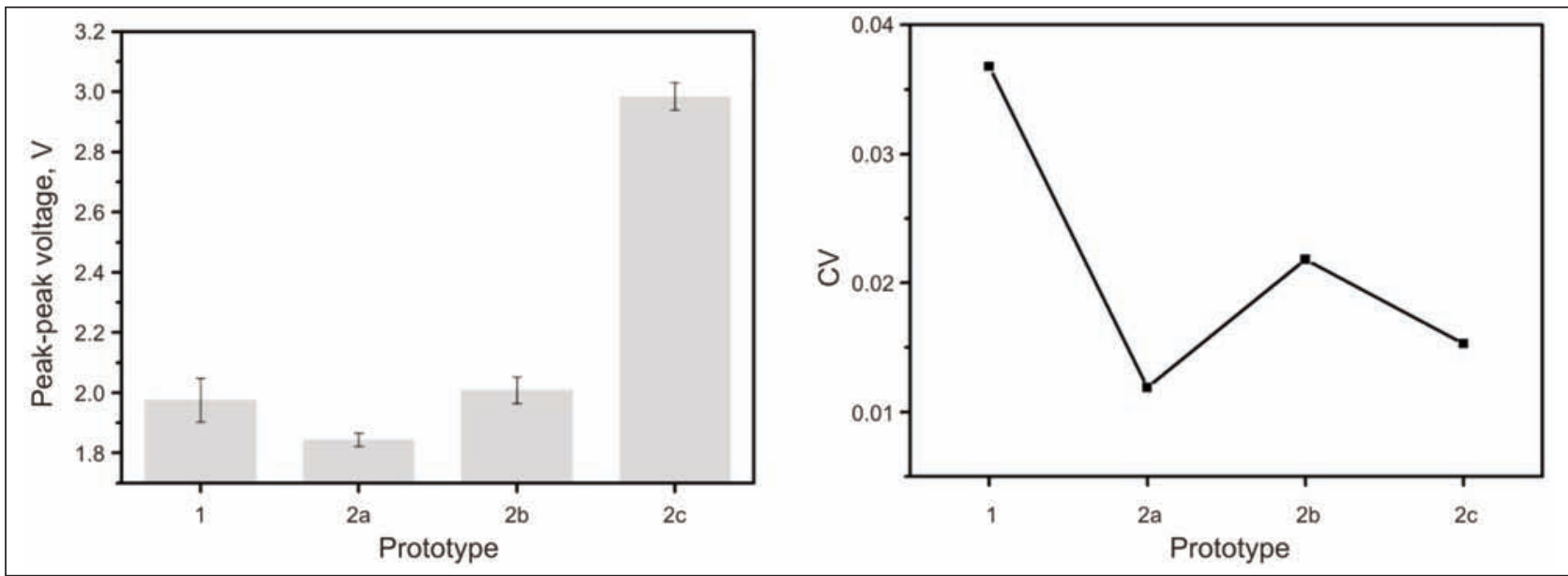

a

b

Fig. 4. $a$ - The peak-peak output voltages of the prototypes; $b$ - The CV of the peak-peak output voltages of the prototypes 
smallest, which means the stability of the output voltage of the prototype 1 is the worst and that of the prototype $2 \mathrm{a}$ is the best. For the prototype 2 , the $\mathrm{CV}$ of the output voltage are not the same, the results reveal that the vertical height of prototype 2 effect the stability of the output voltage.

\section{CONCLUSIONS}

This paper fabricated two mechanical energy harvesters based on piezoelectric effect driven by the impulse excitation. We performed the experiment under $500 \mathrm{~N}$ impulse force at $1 \mathrm{~Hz}$. The experimental results revealed that the two energy harvesters were capable of generating the electricity under low-frequency excitation and the obtained devices exhibit many compelling advantages for practical applications in real environment. The two designed energy harvesters can be used not only in a shoe's heel, but also they are scalable and can be tailored to integrate in commercial carpets or outdoor roadway that converts the massive mechanical energy from the passing vehicles or people crowds into electricity. Though the output power is not very big, $\mathrm{N}$ of the same prototypes can be connected in series or parallel to improve output power in the future work, so the two prototypes are promising and could provide a potential possibility for future green energy.

\section{BIBLIOGRAPHY}

[1] Zhao, J., You, Z.A. Shoe-embedded piezoelectric energy harvester for wearable sensors, In: Sensors, 2014, vol. 14 , no. 7 , pp. 12497-12510.

[2] Pillatsch, P., Yeatman, E.M., Holmes, A.S. Experimental validation of a piezoelectric frequency up-converting rotational harvester, In: 2014 11th International Conference on Wearable and Implantable Body Sensor Networks (Bsn), 2014, vol. 1, pp. 6-10.

[3] Xie,L., Cai, M. Increased piezoelectric energy harvesting from human footstep motion by using an amplification mechanism, In: Applied Physics Letters, 2014, vol. 105, no. 14, p. 143901(1-12).

[4] Ylli, K., Hoffmann, D., Willmann, A., Becker, P., Folkmer, B., Manoli, Y. Energy harvesting from human motion: exploiting swing and shock excitations, In: Smart Materials and Structures, 2015, vol. 24, no. 2, p. 025029.

[5] Naruse, Y., Matsubara, N., Mabuchi, K., Zumi, M., Suzuki, S. Electrostatic micro power generation from low-frequency vibration such as human motion, In: Journal of Micromechanics and Microengineering, 2009, vol. 19, no. 9, p. 094002.

[6] Kim, S L., Choi, K., Tazebay, A., Yu, C., Flexible power fabrics made of carbon nanotubes for harvesting thermoelectricity, In: ACS nano, 2014, vol. 8, no. 3, pp. 2377-2386.

[7] Huang, T., Wang, C., Yu, H., Wang, H., Zhang, Q., Zhu, M. Human walking-driven wearable all-fiber triboelectric nanogenerator containing electrospun polyvinylidene fluoride piezoelectric nanofibers, In: Nano Energy, 2015, vol. 14, pp. 226-235.

[8] Kwon, C.H., Lee, J.A., Choi, Y-B., Kim, H.-H., Spinks, G.M., Lima, M.D., Baughman, R.H., Kim, S.J. Stability of carbon nanotube yarn biofuel cell in human body fluid, In: Journal of Power Sources, 2015, vol. 286, pp. 103-108.

[9] Derman, V. Effects of tourmaline on the voltage response of PVDF filaments, In: Industria textila, 2017, vol. 68, no. 1 , pp. 47-53.

[10] Xin, Y., Li, X., Tian, H., Guo, C., Qian, C., Wang, S., Wang, C. Shoes-equipped piezoelectric transducer for energy harvesting: A brief review, In: Ferroelectrics, 2016, vol. 493, no. 1, pp. 12-24.

[11] Anton, S.R., Sodano, H.A. A review of power harvesting using piezoelectric materials (2003-2006), In: Smart Materials and Structures, vol. 16, no. 3, pp. R1-R21.

[12] Wang, J.-J., Su, H.-J., Hsu, C.-I., Su, Y.-C. Composite piezoelectric rubber band for energy harvesting from breathing and limb motion, In: 14th International Conference on Micro and Nanotechnology for Power Generation and Energy Conversion Applications (Powermems 2014), 2014, vol. 557, p. 012002.

[13] Starner, T., Human-powered wearable computing, In: IBM Systems Journal, 1996, vol. 35, no. 3/4, pp. 618-629.

[14] Kymissis, J., Kendall, C., Paradiso, J., Gershenfeld, N. Parasitic power harvesting in shoes, In: IEEE, 1998, pp. $132-139$.

[15] Moro, L., Benasciutti, D. Harvested power and sensitivity analysis of vibrating shoe-mounted piezoelectric cantilevers, In: Smart Materials and Structures, 2010, vol. 19, no. 11, p. 115011.

[16] Ansari, M.H., Karami, M.A. Energy harvesting from controlled buckling of piezoelectric beams, In: Smart Materials and Structures, 2015, vol. 24, no. 11, p. 115005.

\section{Authors:}

\section{CAO WENYING, YU WEIDONG, LI ZHAOLING}

Donghua University, College of Textiles, Key Laboratory of Textile Science \& Technology, Ministry of Education, 2999 North Renmin Road, Songjiang District, 201620, Shanghai, P.R. China e-mail: 1115133@mail.dhu.edu.cn, wdyu@dhu.edu.cn, zli@dhu.edu.cn

\section{Corresponding author:}

\section{YU WEIDONG}

e-mail:wdyu@dhu.edu.cn 